Article

\title{
Isolation of an Angiotensin I-Converting Enzyme Inhibitory Protein with Antihypertensive Effect in Spontaneously Hypertensive Rats from the Edible Wild Mushroom Leucopaxillus tricolor
}

\section{Xueran Geng ${ }^{1}$, Guoting Tian ${ }^{2}$, Weiwei Zhang ${ }^{1}$, Yongchang Zhao ${ }^{2}$, Liyan Zhao ${ }^{3}$, Mansok Ryu ${ }^{1}$, Hexiang Wang ${ }^{1, *}$ and Tzi Bun Ng ${ }^{4, *}$}

1 State Key Laboratory for Agrobiotechnology and Department of Microbiology, China Agricultural University, Beijing 100193, China; E-Mails: gengxueran2007@163.com (X.G.); zhangweiweicau@gmail.com (W.Z.); 13161825783@163.com (M.R.)

2 Institute of Biotechnology and Germplasmic Resource, Yunnan Academy of Agricultural Science, Kunming 650223, China; E-Mails:tiangt@aliyun.com (G.T.); yaasmushroom@aliyun.com (Y.Z.)

3 College of Food Science and Technology, Nanjing Agricultural University, Weigang, Nanjing 210095, China; E-Mail: zhlychen@njau.edu.cn

4 School of Biomedical Sciences, Faculty of Medicine, The Chinese University of Hong Kong, Shatin, New Territories, Hong Kong, China

* Authors to whom correspondence should be addressed; E-Mails: hxwang@cau.edu.cn (H.W.); b021770@mailserv.cuhk.edu.hk (T.B.N.); Tel./Fax: +86-10-6273-2578 (H.W.); +86-852-2609-8031 (T.B.N.).

Academic Editor: Nancy D. Turner

Received: 5 May 2015 / Accepted: 28 May 2015 / Published: 1 June 2015

Abstract: An 86-kDa homodimeric angiotensin I-converting enzyme (ACE) inhibitory protein designated as LTP was isolated from fruit bodies of the mushroom Leucopaxillus tricolor. The isolation procedure involved ultrafiltration through a membrane with a molecular weight cutoff of 10-kDa, ion exchange chromatography on Q-Sepharose, and finally fast protein liquid chromatography-gel filtration on Superdex 75. LTP exhibited an IC50 value of $1.64 \mathrm{mg} \cdot \mathrm{mL}^{-1}$ for its ACE inhibitory activity. The unique N-terminal amino acid sequence of LTP was disclosed by Edman degradation to be DGPTMHRQAVADFKQ. In addition, seven internal sequences of LTP were elucidated by liquid chromatography-tandem mass spectrometry (LC-MS/MS) analysis. Results of the Lineweaver-Burk plot suggested 
that LTP competitively inhibited ACE. Both LTP and the water extract of L. tricolor exhibited a clear antihypertensive effect on spontaneously hypertensive rats.

Keywords: Leucopaxillus tricolor; ACE inhibitory protein; inhibitory pattern; spontaneously hypertensive rat

\section{Introduction}

According to the World Health Organization (WHO) update in May 2014, cardiovascular disease ranks top among the 10 leading causes of death worldwide. One of the major risk factors for cardiovascular disease is hypertension. It has been estimated that hypertension currently kills nine million people every year $[1,2]$.

Arterial blood pressure is regulated by various factors, including the renin-angiotensin-aldosterone system (RAS). Angiotensin converting enzyme (ACE, EC. 3.4.15.1) is a Zn-metallopeptidase which plays a key role in regulating blood pressure in the RAS. The primary function of ACE is to catalyze the conversion of Ang-I (a decapeptide) to Ang-II (an octapeptide). Ang-II, a potent vasoconstrictor, interacts with the Ang-II type 1 receptor (AT1) and stimulate the secretion of aldosterone, which enhances sodium and water re-absorption in the nephron and therefore elevates blood pressure by increasing the intravascular fluid volume [3-5]. The use of ACE inhibitors has proven to be an effective strategy in the prevention and treatment of hypertension-related diseases, mainly by bringing about a significant alleviation of hypertension, as well as by affording end-organ protection [6]. Since the first discovery in snake venom [7], a diversity of ACE inhibitors including captopril, enalapril, alacepril, lisinopril, perindopril, fosinopril, ramipril, trandolapril, and zofenopril has been synthesized and used clinically as antihypertensive drugs [8,9]. Following the administration of synthetic ACE inhibitors, side effects including coughing, taste disturbances and allergic reactions have been reported. Thus it would be desirable to ascertain and use safe, novel, and relatively inexpensive ACE inhibitors from natural sources.

Many reports are available on bioactive natural constituents from food sources, e.g., grains, fruits, vegetables, nuts, sea foods, dairy products, meats and foods of microbial origin that have potential use in the prevention and treatment of hypertension [10]. Mushrooms are popular not only because of their delicious taste, but also due to their proven nutritional and medicinal effects. Studies on isolation of ACE inhibitors from wild mushrooms are currently lacking in the literature. Recently, researchers have reported that an aqueous extract of Pleurotus ostreatus [11] and an ACE inhibitory peptide from Agaricus bisporus [12] have the potential to inhibit ACE and reduce blood pressure. ACE inhibitory activities of wild mushrooms in Nepal have been tested by Bang and his group [13]. Leucopaxillus tricolor is an edible mushroom which is popular among local Chinese people due to its medicinal value and wide distribution in grasslands. To the best of our knowledge, there are no publications on the biological activity of this mushroom.

Hence, the objectives of this study were to examine the ACE inhibitory activities of fruit body extracts of different mushroom species, purify any ACE inhibitors from the mushrooms, and to subject the crude mushroom extracts and purified ACE inhibitors to in vivo tests of antihypertensive activity using an 
animal model of hypertension. The results of this study disclosed the therapeutic potential of the wild mushroom L. tricolor and added a new L. tricolor ACE inhibitor to the existing pool of ACE inhibitors.

\section{Results and Discussion}

\subsection{ACE Inhibitory Activities of Fruit Body Extracts of Different Mushroom Species}

Extracts from the fruit bodies of 10 wild mushrooms were prepared and their ACE inhibitory activities were tested. As shown in Table 1, the percentages of ACE inhibition achieved were spread over a wide range from $29.2 \%-95 \%$. The highest ACE inhibitory activity (up to 95\% inhibition) was displayed by L. tricolor, followed by Grifola frondosa and Boletus bicolor. The lowest ACE inhibitory activity (30.8\% and 29.2\% inhibition, respectively) was demonstrated by Oudemansiella radicata and Gloeostereum incarnatum. In this study, the water extract of G. frondosa inhibited ACE activity by 77.2\%, whereas 58.7\% inhibition was reported by Choi et al. [14]. Different strains, different extraction methods, and detection methods employed by different investigators may have contributed to a large variation in the ACE inhibitory activity observed. For instance, the extract of $P$. sajor-caju inhibited the activity of ACE by $85.2 \%$ as reported by Lau et al. [15]. On the other hand, in the study of Lee et al. [16], the water extract of this mushroom inhibited ACE activity by $38.7 \%$. The most potent ACE inhibitory activity was pursued further in the current investigation.

Table 1. ACE inhibitory activities of water extracts of various mushrooms a

\begin{tabular}{cc}
\hline Mushroom Species & ACE Inhibitory Activity (\%) of Water Extract \\
\hline Leucopaxillus tricolor & $95.0 \% \pm 0.4$ \\
Grifola frondosa & $77.2 \% \pm 0.5$ \\
Boletus bicolor & $61.3 \% \pm 0.1$ \\
Tuber micheli & $56.5 \% \pm 0.1$ \\
Russula aeruginea & $53.1 \% \pm 0.7$ \\
Boletus edulis & $47.2 \% \pm 0.2$ \\
Morchella vulgaris & $43.3 \% \pm 0.2$ \\
Ramaria botrytoides & $37.8 \% \pm 0.0$ \\
Oudemansiella radicata & $30.8 \% \pm 0.1$ \\
Gloeostereum incarnatum & $29.2 \% \pm 0.9$ \\
\hline
\end{tabular}

a The ratio of mushroom to distilled water (weight to volume) used for preparing the extracts was 1:2. Values were means \pm S.D. of three determinations.

\subsection{Purification of Potential ACE Inhibitor}

L. tricolor ACE inhibitor purification was guided by bioassay. The purification procedure entailed extraction with distilled water, ultrafiltration through a $10-\mathrm{kDa}$ MWCO membrane, followed by ion-exchange chromatography on Q-Sepharose, and finally FPLC on a Superdex 75 column. After the water extract of L. tricolor had been ultrafiltered with a $10-\mathrm{kDa}$ cut-off filter, the cake produced $86.3 \%$ inhibition while the filtrate brought about only $41.4 \%$ inhibition of the ACE activity and thus the cake was employed for further isolation. After adjustment of the $\mathrm{pH}$, the solution of the cake was loaded on 
a Q-Sepharose column and eluted with a linear gradient of $0-1 \mathrm{M} \mathrm{NaCl}$ in $10 \mathrm{mM}$ Tris-HCl buffer ( $\mathrm{pH}$ 7.5). Four fractions, Q1, Q2, Q3 and Q4, were obtained (Figure 1a). The bulk of ACE inhibitory activity resided in fraction Q4. When fraction Q4 was subjected to chromatography on another Q-Sepharose column ( $\mathrm{pH}$ 7.2), the ACE inhibitory activity was located in fraction Q4q2 (Figure 1b). This fraction was further purified on Superdex 75, yielding essentially a single peak (Figure 2a). The first and highest peak (SU1) was the purified ACE inhibitor. According to the elution volume of the peak in FPLC-gel filtration, the molecular mass of the inhibitor named LTP was determined to be about $86 \mathrm{kDa}$.
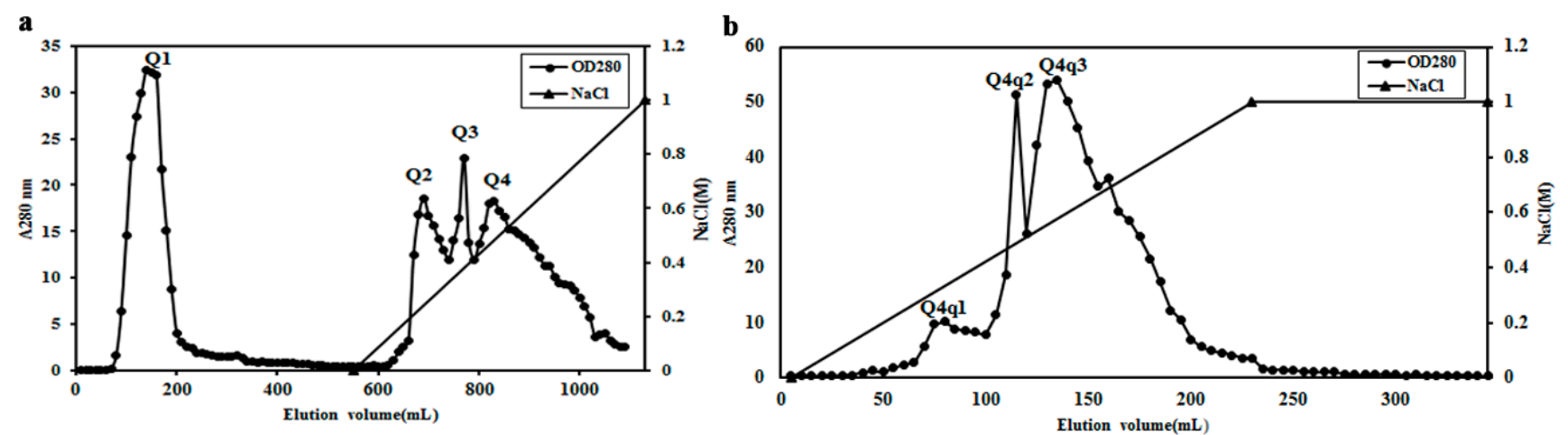

Figure 1. Profiles of purification obtained by ion-exchange chromatography on (a) the first Q-Sepharose column $(3 \mathrm{~cm} \times 25 \mathrm{~cm})$ and $(\mathbf{b})$ the second Q-Sepharose column $(3 \mathrm{~cm} \times 15 \mathrm{~cm})$.

The unadsorbed fraction Q1 was eluted with $10 \mathrm{mM}$ Tris-HCl buffer ( $\mathrm{pH}$ 7.5). The adsorbed fraction was eluted from the column using a linear $(0-1 \mathrm{M}) \mathrm{NaCl}$ gradient in Tris-HCl buffer ( $\mathrm{pH} 7.5)$ as indicated by the slanting line across the right half of the chromatogram. Q4 was the active fraction. (b) Fraction Q4 was loaded on a Q-Sepharose column $(3 \mathrm{~cm} \times 15 \mathrm{~cm})$. The line with triangular symbols indicates elution of adsorbed proteins with a $0-1 \mathrm{M} \mathrm{NaCl}$ gradient in $10 \mathrm{mM}$ Tris- $\mathrm{HCl}$ buffer ( $\mathrm{pH} 7.2)$. ACE inhibitory activity was detected only in fraction Q4q2.
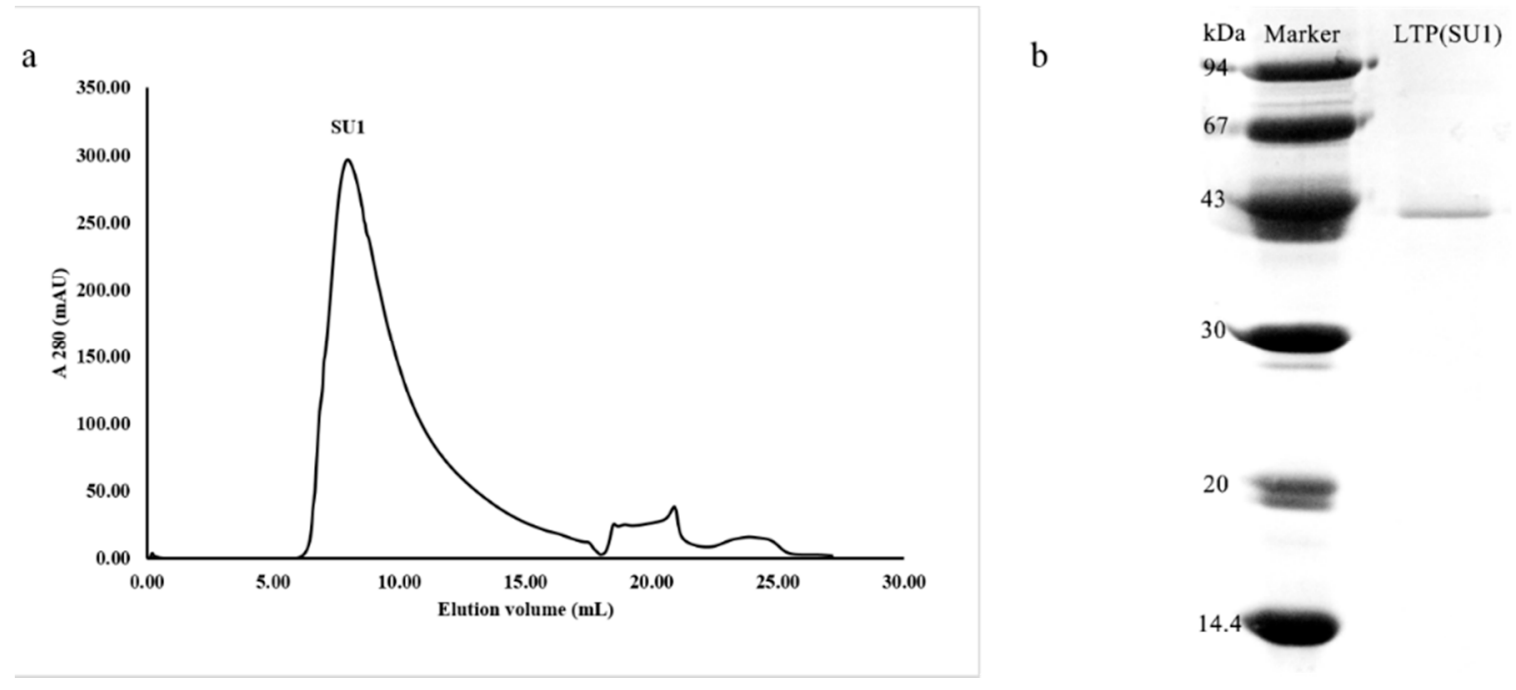

Figure 2. (a) FPLC-gel filtration on Superdex 75 10/300 GL column and (b) SDS-PAGE of fraction SU1. ${ }^{a}$ Eluent: $10 \mathrm{mM}$ Tris-HCl buffer (pH 7.5). Fraction size: $0.8 \mathrm{~mL}$. Flow rate: $0.5 \mathrm{~mL} \cdot \mathrm{min}^{-1}$. Fraction SU1 represents purified ACE inhibitory protein; ${ }^{b}$ SDS-PAGE of fraction SUI. 
The documented bioactive substances for reducing blood pressure include various peptides, phenolic compounds, proteins, polysaccharides, saponins, sterols, pigments, fiber, vitamins $\mathrm{C}$ and $\mathrm{E}$, as well as minerals [10]. A tuber storage protein from yam called dioscorin $(32 \mathrm{kDa})$ purified by DE-52 ion-exchange chromatography, exhibited ACE inhibitory activity [17]. The protein thioredoxin h2 (14 kDa) and a trypsin inhibitor, both from sweet potato storage root, were ACE inhibitors, with IC50 values of $151.8 \mathrm{mg} \cdot \mathrm{mL}^{-1}$ and $187.96 \mathrm{mg} \cdot \mathrm{mL}^{-1}$, respectively $[18,19]$. Mycelia of the edible mushroom Ganoderma lucidum contained several antihypertensive-related proteins, including cystathionine beta synthase-like protein, DEAD/DEAH box helicase-like protein, paxillin-like protein, and alpha/beta hydrolase-like protein, thus G. lucidum has potential in lowering blood pressure [20]. All aforementioned peptides and proteins are exogenous inhibitors. Recently, by ultrafiltering serum, an endogenous ACE inhibitory protein with a molecular weight of about $50-100 \mathrm{kDa}$ was discovered, which may provide a protective mechanism for cardiovascular disease [21]. Here, through a series of purification steps, we acquired an ACE inhibitory protein LTP from the wild edible mushroom L. tricolor, which may be beneficial to hypertensive patients.

Table 2. N-terminal sequences of ACE inhibitory protein from L. tricolor and ACE inhibitory peptides from other mushrooms.

\begin{tabular}{|c|c|c|c|c|}
\hline Mushroom Species & Peptide/Protein & $\begin{array}{c}\text { Mode of } \\
\text { Inhibition of ACE }\end{array}$ & $\begin{array}{c}\text { Mol Weight } \\
\text { (Da) }\end{array}$ & IC $_{50}$ \\
\hline Leucopaxillus tricolor & $\begin{array}{c}(\mathrm{N} \text {-terminal }) \\
\text { DGPTMHRQAVADFKQ }\end{array}$ & competitive & 86,000 & $1.64 \mathrm{mg} \cdot \mathrm{mL}^{-1}$ \\
\hline Agaricus bisporus [12] & $\begin{array}{c}\text { AHEPVK } \\
\text { RIGLF } \\
\text { PSSNK } \\
\end{array}$ & $\begin{array}{c}\text { competitive } \\
\text { competitive } \\
\text { non-competitive }\end{array}$ & $\begin{array}{l}605.3 \\
679.5 \\
532.3 \\
\end{array}$ & $\begin{array}{c}63 \mu \mathrm{M} \\
116 \mu \mathrm{M} \\
129 \mu \mathrm{M} \\
\end{array}$ \\
\hline Tricholoma giganteum [16] & GQP & competitive & 301.1 & $0.04 \mathrm{mg} \cdot \mathrm{mL}^{-1}$ \\
\hline P.cystidiosus [22] & $\begin{array}{l}\text { AHEPVK } \\
\text { GPSMR }\end{array}$ & competitive & $\begin{array}{l}679.5 \\
546.3\end{array}$ & $\begin{array}{c}62.8 \mu \mathrm{M} \\
277.5 \mu \mathrm{M}\end{array}$ \\
\hline Hypsizygus marmoreus [23] & LSMGSASLSP & non-competitive & 567.3 & $0.19 \mathrm{mg} \cdot \mathrm{mL}^{-1}$ \\
\hline G. lucidum [20] & $\begin{array}{c}\text { Cystathionine beta } \\
\text { synthase-like protein, } \\
\text { DEAD/DEAH box } \\
\text { helicase-like protein, } \\
\text { Paxillin-like protein, } \\
\text { Alpha/beta hydrolase-like } \\
\text { protein }\end{array}$ & ND & $\begin{array}{l}49,000 \\
43,700 \\
46,800 \\
37,100\end{array}$ & $<0.2 \mathrm{mg} \cdot \mathrm{mL}^{-1}$ \\
\hline P.cornucopiae [24] & $\begin{array}{c}\text { RLPSEFDLSAFLRA } \\
\text { RLSGQTIEVTSEYLFRH }\end{array}$ & $\begin{array}{c}\text { competitive } \\
\text { non-competitive }\end{array}$ & $\begin{array}{l}1622.8 \\
2037.2\end{array}$ & $\begin{array}{l}0.46 \mathrm{mg} \cdot \mathrm{mL}^{-1} \\
1.14 \mathrm{mg} \cdot \mathrm{mL}^{-1}\end{array}$ \\
\hline Pholiota adiposa [25] & GQGGP & ND & 414.0 & $0.044 \mathrm{mg} \cdot \mathrm{mL}^{-1}$ \\
\hline Grifola frondosa [14] & VIQKYP & competitive & ND & $0.097 \mathrm{mg} \cdot \mathrm{mL}^{-1}$ \\
\hline
\end{tabular}

"ND" means "Not Detected".

Table 2 lists the ACE inhibitory proteins and peptides from various edible mushrooms. Peptides from Tricholoma giganteum and Pholiota adiposa exhibited ACE inhibitory activity with the lowest IC 50 values which were $0.040 \mathrm{mg} \cdot \mathrm{mL}^{-1}$ and $0.044 \mathrm{mg} \cdot \mathrm{mL}^{-1}$, respectively. The ACE inhibitory protein from 
L. tricolor manifested ACE inhibitory activity with higher $\mathrm{IC}_{50}$ value $\left(1.64 \mathrm{mg} \cdot \mathrm{mL}^{-1}\right)$ among the listed mushroom ACE inhibitors. It was previously mentioned that the IC50 values of ACE inhibitory activity of two ACE inhibitory proteins from sweet potato storage root were $151.8 \mathrm{mg} \cdot \mathrm{mL}^{-1}$ and $187.96 \mathrm{mg} \cdot \mathrm{mL}^{-1}$, respectively $[18,19]$. We can see that the ACE inhibitory protein from L. tricolor had a higher ACE IC50 value than peptides, which may be attributed to its large size and increased difficulty to access the active site of ACE than peptides.

The similarity of this study and the study on peptide from fertilized eggs [26] is the purification characteristic, both use ion-exchange chromatography and FPLC, without using RP-HPLC. Most of the purification methods for ACE inhibitors included HPLC (Table 2), like that on peptide from walnut protein [27] and so on. RP-HPLC is the predominant technique used in the purification of peptides with antihypertensive activity [28]. Among Superdex columns, the Peptide 10/300 GL column and Peptide HR 10/30 column are mostly chosen to purify compounds with M.W.s ranging from 100 to 7000 [29]. Because the LTP is a protein, the Superdex 75 HR column was employed.

\subsection{Identification of the ACE Inhibitor}

The finding of a single band in SDS-PAGE for purified LTP, coupled with the results of Superdex 75 chromatography, led us to conclude that the ACE inhibitor LTP was a homodimer with a molecular mass of $86 \mathrm{kDa}$ (Figure $2 \mathrm{~b}$ ) within the molecular mass range of endogenous ACE inhibitors which runs from 50 to $100 \mathrm{kDa}[21]$.

The N-terminal amino acids sequence of LTP was DGPTMHRQAVADFKQ and was compared with those protein and peptides of other reported edible mushrooms in Table 2. According to the report of Wu et al., for tripeptides, the most favorable residues for the carboxyl terminus are aromatic amino acids, while the intermediate are the positively charged amino acids, and hydrophobic amino acids are preferred for the N-terminus [30]. This is in line with the findings of Lau and coworkers [22] which show that the hydrophobicity of amino acids have great influence on ACE inhibitory activity. The percentage of hydrophobicity of the N-terminal amino acids of ACE inhibitor protein LTP was $40 \%$. The high percentage of hydrophobicity was in agreement with the characteristic of ACE inhibitor.

Table 3. Internal amino acid sequences of ACE inhibitor from L. tricolor identified by LC-MS/MS.

\begin{tabular}{ccccc}
\hline Identified Peptide & $\begin{array}{c}\text { Percentage of } \\
\text { Hydrophobic } \\
\text { Amino Acids (\%) }\end{array}$ & Mass & $\mathbf{m / z}$ & $\begin{array}{c}\text { Expected } \\
\text { Value }\end{array}$ \\
\hline VLITTDLLAR & 60.0 & 1113.6732 & 557.8439 & 0.047 \\
LAVNMVPFPR & 80.0 & 1142.624 & 572.3193 & 0.06 \\
ALLFGISGLR & 60.0 & 1045.6632 & 523.8389 & 0.13 \\
VAPEEHPVLLTEAPLNPK & 61.1 & 1953.0543 & 652.0254 & 5.6 \\
AVGKVLPALAGK & 66.7 & 1122.6681 & 562.3413 & 7.7 \\
FELTGIPPAPPR & 66.7 & 1293.6608 & 432.2275 & 22 \\
AAGGVAALLK & 70.0 & 869.5336 & 435.7741 & 24 \\
\hline
\end{tabular}

Hydrophobic amino acid residues are underlined.

Several internal sequences of the purified ACE inhibitory protein LTP were elucidated by LC-MS/MS using a LTQ-Orbitrap mass spectrometer. As shown in Table 3, there were seven peptides containing 
more hydrophobic amino acid residues and all the N-terminal amino acids were hydrophobic residues, which was in accordance with the characteristic of the potential ACE inhibitor. The ACE inhibitory protein LTP contained these peptides and the N-terminal amino acids were also in agreement with the characteristic of ACE inhibitor, hence we can conclude that the purified LTP indeed was an ACE inhibitor and deserves further study.

\subsection{Mode of Inhibition of ACE Inhibitor}

A Lineweaver-Burk plot was used to analyze the inhibition pattern of the purified ACE inhibitor LTP. As shown in Figure 3, with the increase of the concentration of LTP (from 0 to $1 \mathrm{mg} \cdot \mathrm{mL}^{-1}$ ), three straight lines intersected at the same point on the $1 / v$ axis of the Lineweaver-Burk plot, indicating the same maximum velocity regardless of inhibitor concentration, whereas the slopes of these straight lines differed. Thus it was concluded that the purified ACE inhibitor LTP was a competitive inhibitor. Competitive ACE inhibitors purified from edible mushrooms, such as A. bisporus, T. giganteum, $P$. cystidiosus, $P$. cornucopiae and $G$. frondosa have been reported (Table 2). Noncompetitive inhibitors are found in A. bisporus, Hypsizygus marmoreus and P. cornucopiae. From Table 2, it can see that both competitive and non-competitive ACE inhibitors were found in A. bisporus and P. cornucopiae [12,14,16,22-24]. There were also competitive ACE inhibitors isolated from other food sources, for example, hen's eggs and marine shrimps [31,32]. Unfortunately, the relationship between the mode of inhibition and structure of these peptides has not been elucidated [33].

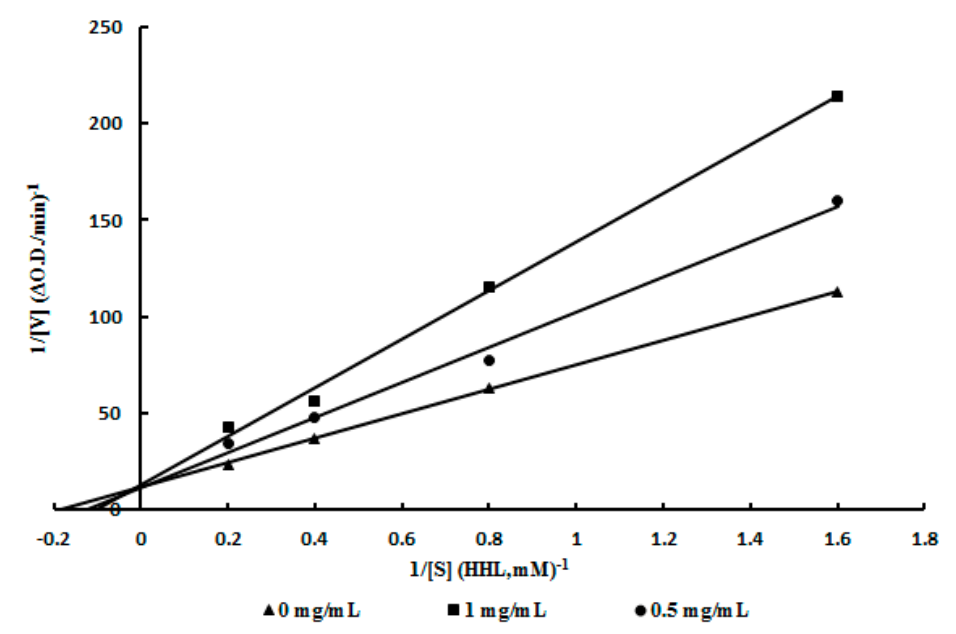

Figure 3. The pattern of LTP to ACE. Lineweaver-Burk plot of ACE inhibitor LTP: ( $\Delta$ ) control, (•) $0.5 \mathrm{mg} \mathrm{LTP} / \mathrm{mL}$, and $(\boldsymbol{\bullet}) 1 \mathrm{mg} \mathrm{LTP} / \mathrm{mL}$. The intersection of the three lines on the vertical axis signified that the purified ACE inhibitor LTP was a competitive inhibitor.

\subsection{Antihypertensive Action of the Purified ACE Inhibitor}

In the single-dose and short-time test, the antihypertensive activity of LTP was evaluated by measuring the SBP in SHRs at 0.5, 2, 4, 6 and $8 \mathrm{~h}$ after oral administration as shown in Figure 4. Half an hour after administration of captopril (100 mg. $\left.\mathrm{kg}^{-1} \mathrm{BW}\right)$, LTP $\left(100 \mathrm{mg} \cdot \mathrm{kg}^{-1} \mathrm{BW}\right)$ and the crude extract of L. tricolor (200 mg $\left.\mathrm{kg}^{-1} \mathrm{BW}\right)$, the blood pressure of all three groups had undergone a slight decrease. The maximum decline exhibited by the three groups was observed at $2 \mathrm{~h}$, and the decrements 
in SBP were 38, 34 and $43 \mathrm{mmHg}$, respectively. Subsequently the blood pressure of all groups increased gradually. The dosage of crude extract of $L$. tricolor was $200 \mathrm{mg} \cdot \mathrm{kg}^{-1}$, which corresponded to $0.58 \mathrm{~g}$ of dried L. tricolor. This may provide evidence for L. tricolor being a functional food. Furthermore, no allergic reactions or coughing was observed on the day of the experiment and on the following day.

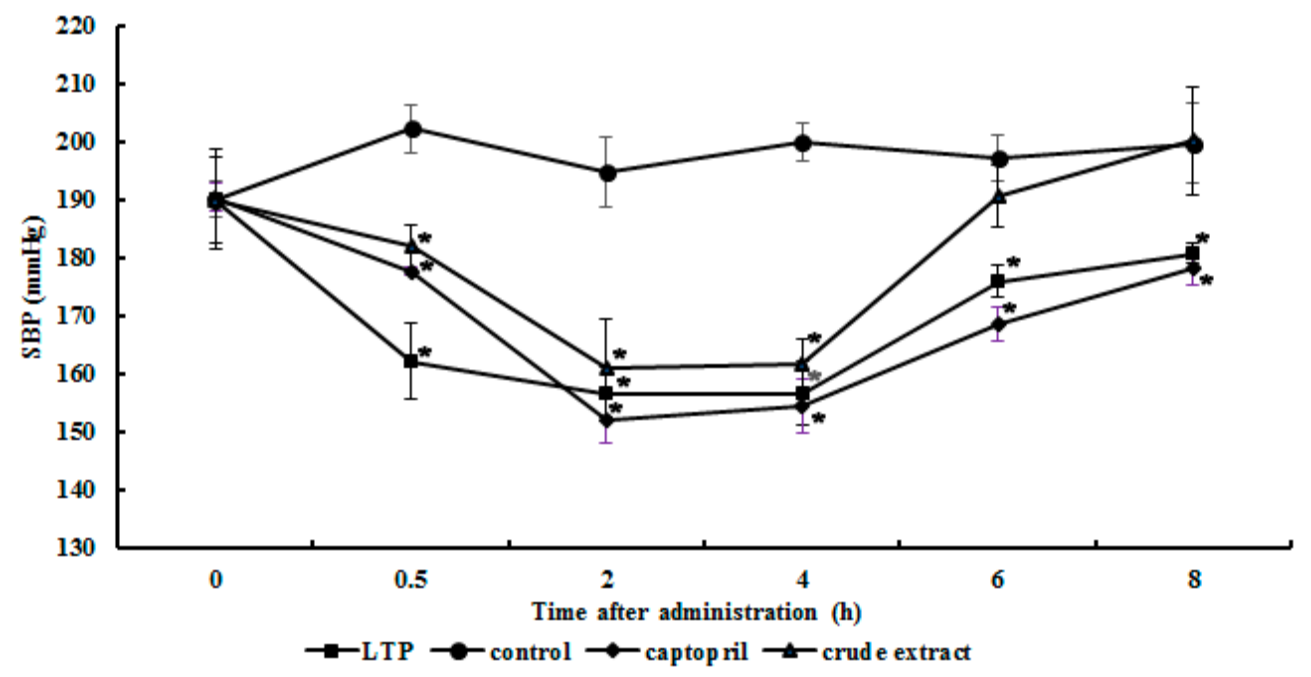

Figure 4. Changes in systolic blood pressure (SBP) of spontaneously hypertensive rats after oral administration of purified ACE inhibitor LTP and water extract of L. tricolor. Single oral administrations were performed with a dosage of $100 \mathrm{mg} \mathrm{LTP} / \mathrm{kg}$ body weight and $200 \mathrm{mg}$ water extract $/ \mathrm{kg}$ body weight, respectively. SBP was measured 0, 0.5, 2, 4, 6 and $8 \mathrm{~h}$ after administration. (*) Significantly different from control at $p<0.05$ by student's $t$-test. $(\bullet)$, $0.9 \%$ saline solution; $(\bullet)$, captopril; $(\boldsymbol{\bullet})$, ACE inhibitor LTP; $(\boldsymbol{\Delta})$, water extract of L. tricolor.

There have been many reports on the antihypertensive effect of edible mushrooms and other foodstuff on SHRs. The water extract of H. marmoreus at the dosage of $800 \mathrm{mg} \cdot \mathrm{kg}^{-1}$ brought about a $14.4 \%$ decrease in blood pressure in SHRs from $180 \mathrm{mmHg}$ to $154 \mathrm{mmHg}$ [23]. In the present study, the water extract of L. tricolor $\left(200 \mathrm{mg} \cdot \mathrm{kg}^{-1}\right)$ lowered the blood pressure by nearly $22.6 \%$, but the reduction was less than that effected by P. cornucopiae (27.8\%) [24]. Other components from mushrooms had also been investigated, for instance, in a single-dose test, the protein fraction, hot water extract and polysaccharide fraction from $P$. nebrodensis decreased SBP in SHRs. In a continuous-dose, the dry power and non-dialyzable fraction from $P$. nebrodensis also showed suppression of increase in blood pressure [34]. This may explain why the crude extract of L. tricolor had similar effect to the purified ACE inhibitor LTP in lowering the blood pressure.

\section{Experimental Section}

\subsection{Materials}

Fruiting bodies of Leucopaxillus tricolor were collected from Hailaer (in Mongolia Province) and identified by ITS. Grifola frondosa, Gloeostereum incarnatum and Oudemansiella radicata were purchased from a local market in Beijing. Russula aeruginea, Morchella vulgaris, Ramaria botrytoides, Boletus bicolor, Tuber micheli, and Boletus edulis were collected from Yunnan Province in China. 
Phenylmethylsulfonyl fluoride (PMSF), rabbit lung ACE, and hippuryl-L-histidyl-L-leucine (HHL) were purchased from Sigma-Aldrich (St. Louis, MO, USA). All solvents and chemicals used in this study were of analytical and HPLC grade. Twelve-week-old male spontaneously hypertensive rats (SHRs) were purchased from Beijing Vital River Experimental Animal Technical Co., Ltd. (Beijing, China).

\subsection{Purification of ACE Inhibitor}

Dried fruiting bodies (200 g) of L. tricolor were blended in distilled water $(1: 20, \mathrm{w}: \mathrm{v})$ at $4{ }^{\circ} \mathrm{C}$ overnight. The mixture was centrifuged at $9000 \mathrm{rpm}$ for $20 \mathrm{~min}$ at $4{ }^{\circ} \mathrm{C}$, and the supernatant was subjected to ultrafiltration with a 10,000 M.W. cut-off membrane (Labscal TFF System, Millipore Co., Billerica, MA, USA).The filtrate and solution of the filter-cake were assayed for ACE inhibitory activity as described below. The active fraction was loaded on a Q-Sepharose column $(3 \mathrm{~cm} \times 25 \mathrm{~cm}$, GE Healthcare, Uppsala, Sweden) which had previously been equilibrated with $10 \mathrm{mM}$ Tris-HCl buffer ( $\mathrm{pH} 7.5)$, and then eluted with a linear gradient of $0-1 \mathrm{M} \mathrm{NaCl}$ in the same buffer. After dialysis, the fraction with ACE inhibitory activity was chromatographed on another Q-Sepharose column $(3 \mathrm{~cm} \times 15 \mathrm{~cm})$, and eluted with a $0-1 \mathrm{M} \mathrm{NaCl}$ concentration gradient in $10 \mathrm{mM}$ Tris- $\mathrm{HCl}$ buffer ( $\mathrm{pH}$ 7.2). Following dialysis, the active fraction was further purified by fast protein liquid chromatography (FPLC) on a gel filtration Superdex 75 10/300 GL column (GE Healthcare, Uppsala, Sweden) in $10 \mathrm{mM}$ Tris-HCl buffer (pH 7.5) using an AKTA Purifier (GE Healthcare, Uppsala, Sweden).

\subsection{Assay of ACE Inhibitory Activity}

ACE was prepared following the protocol described by Hayakari et al. [35] with some modifications. Briefly, a fresh rabbit lung ( $5 \mathrm{~g}$ ) without connective tissues was washed with pre-cooled $\mathrm{NaCl}$ solution $(0.15 \mathrm{M})$, cut into pieces, and then homogenized in $45 \mathrm{~mL}$ ice-cold $0.1 \mathrm{M}$ sodium borate buffer, $\mathrm{pH} 8.3$, containing $0.25 \mathrm{M}$ sucrose and $0.1 \mathrm{mM}$ PMSF. The homogenate was dialyzed overnight in $0.1 \mathrm{M}$ sodium borate buffer, $\mathrm{pH} 8.3$ at $4{ }^{\circ} \mathrm{C}$. The mixture was then centrifuged at $9000 \mathrm{rpm}$ for $40 \mathrm{~min}$ at $4{ }^{\circ} \mathrm{C}$, and the resulting supernatant was centrifuged at $9000 \mathrm{rpm}$ for $40 \mathrm{~min}$ at $4{ }^{\circ} \mathrm{C}$. The supernatant was aliquoted and stored at $-20{ }^{\circ} \mathrm{C}$ for further experiments.

ACE inhibitory activity was assayed as described by Cushman et al. [36] with modifications. The reaction mixture containing $20 \mu \mathrm{L}$ ACE from rabbit lungs and $20 \mu \mathrm{L}$ inhibitor was pre-incubated for 5 min at $37^{\circ} \mathrm{C}$, and then $150 \mu \mathrm{L}$ of $5 \mathrm{mM} \mathrm{HHL}(0.1 \mathrm{M}$, sodium borate buffer $\mathrm{pH} 8.3$ and $0.3 \mathrm{M} \mathrm{NaCl})$ was added to start the reaction. The reaction was terminated by the addition of $500 \mu \mathrm{L}$ of $1 \mathrm{M} \mathrm{HCl}$ after incubation for $30 \mathrm{~min}$. The liberated hippuric acid was extracted with $1.2 \mathrm{~mL}$ of ethyl acetate, and $0.8 \mathrm{~mL}$ of the extract was heat-evaporated at $95{ }^{\circ} \mathrm{C}$ for $35 \mathrm{~min}$ to remove the ethyl acetate. The residue was then dissolved in $0.8 \mathrm{~mL}$ distilled water and measured spectrophotometrically at $228 \mathrm{~nm}$ to estimate ACE inhibitory activity. The activity was calculated using the following formula:

$$
\text { Inhibition activity }(\%)=\left(1-\frac{A-B}{C-D}\right) \times 100
$$

where $\mathrm{A}$ is the absorbance of $\mathrm{ACE}+$ distilled water, $\mathrm{B}$ is the absorbance of distilled water, $\mathrm{C}$ is the absorbance of $\mathrm{ACE}+$ inhibitor, and $\mathrm{D}$ is the absorbance of inhibitor + water. The concentration of the inhibitor required to inhibit $50 \%$ of the ACE activity under the above assay conditions was defined as $\mathrm{IC}_{50}$. 


\subsection{Molecular Mass Determination and Amino Acid Sequence Analysis of the Isolated ACE Inhibitor}

The molecular mass of the purified ACE inhibitor was determined by sodium dodecyl sulfate-polyacrylamide gel electrophoresis (SDS-PAGE) and gel filtration using an FPLC system. SDS-PAGE was conducted in accordance with the procedure of Laemmli and Favre, using a 15\% resolving gel and a 5\% stacking gel [37]. Gel filtration was carried out using a Superdex 75 10/300 GL column, which had been calibrated with molecular mass standards.

The N-terminal amino acid sequence of the inhibitor was analyzed by automated Edman degradation using a Perkin Elmer protein sequencer (Model 491, Applied Biosystems, Foster, CA, USA). Identification of the peptide sequences of the purified inhibitor was performed as follows: the inhibitor was digested with trypsin and then dissolved in $0.1 \%$ formic acid and $2 \%$ acetonitrile for liquid chromatography-tandem mass spectrometry (LC-MS/MS) analysis using a LTQ-Orbitrap mass spectrometer (Thermo Electron, Bremen, Germany).

\subsection{Determination of Mode of Inhibition of ACE}

To determine the type of inhibition of ACE by the purified inhibitor, various concentrations $(0.63$, $1.25,2.5$ and $5 \mathrm{mM}$ ) of HHL were incubated with ACE in the absence and presence of the inhibitor at two different concentrations $\left(1 \mathrm{mg} \cdot \mathrm{mL}^{-1}\right.$ and $\left.0.05 \mathrm{mg} \cdot \mathrm{mL}^{-1}\right)$. The ACE inhibitory activity was determined following the aforementioned method. From the Lineweaver-Burk plot, the kinetic parameters $\mathrm{V}_{\max }$ and $\mathrm{K}_{\mathrm{m}}$ in the absence and presence of the inhibitor were determined.

\subsection{Antihypertensive Action in Spontaneously Hypertensive Rats (SHRs)}

All experiments were performed in accordance with the Regulations of Experimental Animal Administration issued by the State Committee of Science and Technology of the People's Republic of China and with the approval of the Animal Experimentation Ethics Committee of The Chinese University of Hong Kong which had been procured prior to the animal experiments. The SHRs were fed acclimatized for a week, housed in cages and maintained in an air-conditioned room $\left(25 \pm 1{ }^{\circ} \mathrm{C}\right)$ and kept on a 12:12 light-dark cycle. Food and tap water were provided ad libitum. During the acclimatization period prior to the test, the blood pressures of the rats were measured four times weekly.

The rats were divided into four groups, with each group containing four rats: $0.9 \%$ saline solution was administered orally to the blank control group. The inhibitor group received $100 \mathrm{mg}$ inhibitor $/ \mathrm{kg}$ body weight, and the crude water extract group received $200 \mathrm{mg}$ crude water extract of L. tricolor $/ \mathrm{kg}$ body weight. The inhibitor was dissolved in the same volume of saline solution for administration. The systolic blood pressure (SBP) was measured by the tail-cuff method with a programmable BP-100A electro-sphygmomanometer (Chengdu Taimeng Software Co., Ltd., Chengdu, China) before drug/sample administration, and again $0.5,2,4,6$ and $8 \mathrm{~h}$ after drug/sample administration.

\section{Acknowledgements}

This work was financially supported by China Agriculture Research System (CARS24) and Special Fund for Agro-scientific Research in the Public Interest (No. 201303080). 


\section{Author Contributions}

X.G. performed the experiments. G.T. collected the data. W.Z. analysed the data. Y.Z. and L.Z. contributed materials and reagents. M.R. assisted perform the experiments. H.W. conceived and designed the study. T.B.N. wrote the manuscript.

\section{Conflicts of Interest}

The authors declare no conflict of interest.

\section{References}

1. WHO. Mortality and Global Health Estimates: Causes of Death-Ten Leading Causes of Death. Available online: http://apps.who.int/gho/data/view.wrapper.MGHEMORTCAUSE102012?lang=en\&menu=hide (accessed on 29 July 2014).

2. WHO. A Global Brief on Hypertension. Available online: http://www.who.int/ cardiovascular_diseases/publications/global brief hypertension/en/ (accessed on 29 July 2014).

3. Lafarga, T.; Hayes, M. Bioactive peptides from meat muscle and by-products: Generation, functionality and application as functional ingredients. Meat. Sci. 2014, 98, 227-239.

4. Shearer, F.; Lang, C.C.; Struthers, A.D. Renin-angiotensin-aldosterone system inhibitors in heart failure. Clin. Pharmacol. Ther. 2013, 94, 459-467.

5. Quist, E.E.; Phillips, R.D.; Saalia, F.K. Angiotensin converting enzyme inhibitory activity of proteolytic digests of peanut (Arachis hypogaea L.) flour. Lwt-Food Sci. Technol. 2009, 42, 694-699.

6. Brown, N.J.; Vaughan, D.E. Angiotensin-converting enzyme inhibitors. Circulation 1998, 97, 1411-1420.

7. Ferreira, S.H.; Bartelt, D.C.; Greene, L.J. Isolation of bradykinin-potentiating peptides from Bothrops jararaca venom. Biochemistry 1970, 9, 2583-2593.

8. Vercruysse, L.; Van Camp, J.; Smagghe, G. ACE inhibitory peptides derived from enzymatic hydrolysates of animal muscle protein: A review. J. Agric. Food. Chem. 2005, 53, 8106-8115.

9. Hernandez, A.F.; Harrington, R.A. Comparative effectiveness of angiotensin-converting-enzyme inhibitors: Is an ACE always an ace? Can. Med. Assoc. J. 2008, 178, 1316-1319.

10. Huang, W.Y.; Davidge, S.T.; Wu, J. Bioactive natural constituents from food sources-potential use in hypertension prevention and treatment. Crit. Rev. Food Sci. Nutr. 2013, 53, 615-630.

11. Ebigwai, J.K.; Edu, E.A.; Itam, E.H.; Mofunanya, A.J. Activity of crude cold-water extract of the culinary-medicinal oyster mushroom, Pleurotus ostreatus (Jacq.: Fr.) P. Kumm. (higher Basidiomycetes), and timolol maleate on induced ocular hypertension. Int. J. Med. Mushrooms 2012, 14, 467-470.

12. Lau, C.C.; Abdullah, N.; Shuib, A.S.; Aminudin, N. Novel angiotensin I-converting enzyme inhibitory peptides derived from edible mushroom Agaricus bisporus (J.E. Lange) Imbach identified by LC-MS/MS. Food Chem. 2014, 148, 396-401. 
13. Hai Bang, T.; Suhara, H.; Doi, K.; Ishikawa, H.; Fukami, K.; Parajuli, G.P.; Katakura, Y.; Yamashita, S.; Watanabe, K.; Adhikari, M.K.; et al. Wild mushrooms in nepal: Some potential candidates as antioxidant and ACE-inhibition sources. Evid. Based Complement. Alternat. Med. 2014, 2014, doi:10.1155/2014/195305.

14. Choi, H.S.; Cho, H.Y.; Yang, H.C.; Ra, K.S.; Suh, H.J. Angiotensin I-converting enzyme inhibitor from Grifola frondosa. Food Res. Int. 2001, 34, 177-182.

15. Lau, C.C.; Abdullah, N.; Shuib, A.S.; Aminudin, N. Proteomic analysis of antihypertensive proteins in edible mushrooms. J. Agric. Food. Chem. 2012, 60, 12341-12348.

16. Hyoung Lee, D.; Ho Kim, J.; Sik Park, J.; Jun Choi, Y.; Soo Lee, J. Isolation and characterization of a novel angiotensin I-converting enzyme inhibitory peptide derived from the edible mushroom Tricholoma giganteum. Peptides 2004, 25, 621-627.

17. Hsu, F.L.; Lin, Y.H.; Lee, M.H.; Lin, C.L.; Hou, W.C. Both dioscorin, the tuber storage protein of yam (Dioscorea alata cv. Tainong No. 1), and its peptic hydrolysates exhibited angiotensin converting enzyme inhibitory activities. J. Agric. Food. Chem. 2002, 50, 6109-6113.

18. Huang, G.J.; Chen, H.J.; Susumu, K.; Wu, J.B.; Hou, W.C.; Wu, C.H.; Sheu, M.J.; Huang, S.S.; Lin, Y.H. Sweet potato storage root thioredoxin h2 and their peptic hydrolysates exhibited angiotensin converting enzyme inhibitory activity in vitro. Bot. Stud. 2011, 52, 15-22.

19. Huang, G.J.; Ho, Y.L.; Chen, H.J.; Chang, Y.S.; Huang, S.S.; Hung, H.J.; Lin, Y.H. Sweet potato storage root trypsin inhibitor and their peptic hydrolysates exhibited angiotensin converting enzyme inhibitory activity in vitro. Bot. Stud. 2008, 49, 101-108.

20. Mohamad Ansor, N.; Abdullah, N.; Aminudin, N. Anti-angiotensin converting enzyme (ACE) proteins from mycelia of Ganoderma lucidum (Curtis) P. Karst. BMC Complement. Altern. Med. 2013, 13, doi:10.1186/1472-6882-13-256.

21. Fagyas, M.; Uri, K.; Siket, I.M.; Darago, A.; Boczan, J.; Banyai, E.; Edes, I.; Papp, Z.; Toth, A. New perspectives in the renin-angiotensin-aldosterone system (RAAS) I: Endogenous angiotensin converting enzyme (ACE) inhibition. PLoS ONE 2014, 9, e87843.

22. Lau, C.C.; Abdullah, N.; Shuib, A.S. Novel angiotensin I-converting enzyme inhibitory peptides derived from an edible mushroom, Pleurotus cystidiosus O.K. Miller identified by LC-MS/MS. BMC Complement. Altern. Med. 2013, 13, doi:10.1186/1472-6882-13-313.

23. Kang, M.G.; Kim, Y.H.; Bolormaa, Z.; Kim, M.K.; Seo, G.S.; Lee, J.S. Characterization of an antihypertensive angiotensin I-converting enzyme inhibitory peptide from the edible mushroom Hypsizygus marmoreus. BioMed Res. Int. 2013, 2013, doi:10.1155/2013/283964.

24. Jang, J.H.; Jeong, S.C.; Kim, J.H.; Lee, Y.H.; Ju, Y.C.; Lee, J.S. Characterisation of a new antihypertensive angiotensin I-converting enzyme inhibitory peptide from Pleurotus cornucopiae. Food Chem. 2011, 127, 412-418.

25. Koo, K.C.; Lee, D.H.; Kim, J.H.; Yu, H.E.; Park, J.S.; Lee, J.S. Production and characterization of antihypertensive angiotensin I-converting enzyme inhibitor from Pholiota adiposa. J. Microbiol. Biotechnol. 2006, 16, 757-763.

26. Duan, X.; Wu, F.; Li, M.; Yang, N.; Wu, C.; Jin, Y.; Yang, J.; Jin, Z.; Xu, X. Naturally occurring angiotensin I-converting enzyme inhibitory peptide from a fertilized egg and its inhibitory mechanism. J. Agric. Food. Chem. 2014, 62, 5500-5506. 
27. Liu, M.; Du, M.; Zhang, Y.; Xu, W.; Wang, C.; Wang, K.; Zhang, L. Purification and identification of an ACE inhibitory peptide from walnut protein. J. Agric. Food. Chem. 2013, 61, 4097-4100.

28. Herraiz, T. Sample preparation and reversed phase-high performance liquid chromatography analysis of food-derived peptides. Anal. Chim. Acta 1997, 352, 119-139.

29. Puchalska, P.; Alegre, M.L.; Lopez, M.C. Isolation and characterization of peptides with antihypertensive activity in foodstuffs. Crit. Rev. Food Sci. Nutr. 2013, 55, 521-551.

30. Wu, J.; Aluko, R.E.; Nakai, S. Structural requirements of angiotensin I-converting enzyme inhibitory peptides: Quantitative structure-activity relationship study of di- and tripeptides. J. Agric. Food. Chem. 2006, 54, 732-738.

31. Rao, S.; Sun, J.; Liu, Y.; Zeng, H.; Su, Y.; Yang, Y. ACE inhibitory peptides and antioxidant peptides derived from in vitro digestion hydrolysate of hen egg white lysozyme. Food Chem. 2012, 135, 1245-1252.

32. Hai-Lun, H.; Xiu-Lan, C.; Cai-Yun, S.; Yu-Zhong, Z.; Bai-Cheng, Z. Analysis of novel angiotensin-I-converting enzyme inhibitory peptides from protease-hydrolyzed marine shrimp Acetes chinensis. J. Pept. Sci. 2006, 12, 726-733.

33. Ni, H.; Li, L.; Liu, G.; Hu, S.Q. Inhibition mechanism and model of an angiotensin I-converting enzyme (ACE)-inhibitory hexapeptide from yeast (Saccharomyces cerevisiae). PLoS ONE 2012 , 7, e37077.

34. Miyazawa, N.; Okazaki, M.; Ohga, S. Antihypertensive effect of Pleurotus nebrodensis in spontaneously hypertensive rats. J. Oleo Sci. 2008, 57, 675-681.

35. Hayakari, M.; Kondo, Y.; Izumi, H. A rapid and simple spectrophotometric assay of angiotensin-converting enzyme. Anal. Biochem. 1978, 84, 361-369.

36. Cushman, D.W.; Cheung, H.S.; Sabo, E.F.; Ondetti, M.A. Design of potent competitive inhibitors of angiotensin-converting enzyme. Carboxyalkanoyl and mercaptoalkanoyl amino acids. Biochemistry 1977, 16, 5484-5491.

37. Laemmli, U.K.; Favre, M. Maturation of the head of bacteriophage T4. I. DNA packaging events. J. Mol. Biol. 1973, 80, 575-599.

Sample Availability: Samples of the compounds are available from the authors.

(C) 2015 by the authors; licensee MDPI, Basel, Switzerland. This article is an open access article distributed under the terms and conditions of the Creative Commons Attribution license (http://creativecommons.org/licenses/by/4.0/). 